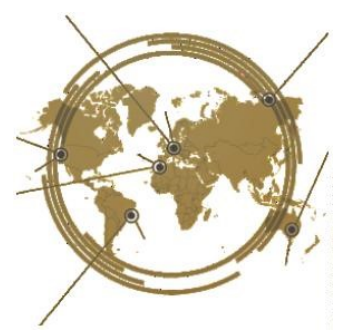

\title{
Jeopardy classroom instruction: Fostering students' motivation to learn English vocabulary
}

Widya Ratna Kusumaningrum ${ }^{1 *}$, Endang Binarti ${ }^{2}$

${ }^{1}$ Pendidikan Bahasa Inggris, Jurusan Bahasa dan Seni, Fakultas Keguruan dan Ilmu Pendidikan, Universitas Tidar, Kota Magelang, Jawa Tengah, Indonesia, 2SMP Negeri 1 Magelang, Kota Magelang, Jawa Tengah, Indonesia

The issue, dealing with gamification to foster learners' motivation and vocabulary in learning English, has been investigated recently. It is perceived that gamification will directly affect the teaching-learning process and determine the learning ambiance. This study aims to shed light on the extent of the employment of Jeopardy Classroom Instruction to foster EFL learners' motivation to learn English vocabulary. The study deployed an action research method with three phases of pre-cycle, cycle 1 , and cycle 2. Pre-cycle was to document the initial classroom condition before using Jeopardy Classroom Instruction, while cycle 1 and cycle 2 were for knowing the teaching-learning process situation during the use of Jeopardy Classroom Instruction. The participants were junior high school students. The data were collected through observation, closed-ended questionnaire, and students' score. The results suggested that Jeopardy Classroom Instruction is an adjunct to aid students' motivation to learn vocabulary. It helped students to acquire self-belief, learning focus, the value of learning, study management, planning and monitoring and persistence. Also, it mitigated some motivation guzzlers such as learning anxiety, low control, failure avoidance, and self-sabotage that might hinder them from learning vocabulary.

\section{Keywords: learning motivation, Jeopardy, action research, vocabulary learning, gamification}

OPEN ACCESS

ISSN 25033492 (online)

${ }^{*}$ Correspondence:

Widya Ratna Kusumaningrum

kusumaningrum@untidar.ac.id

Received: 26th January 2021

Accepted: 24th April 2021

Published: 24th April 2021

Citation:

Kusumaningrum, W. R. and Binarti,

E. (2021). Jeopardy classroom

instruction: Fostering students'

motivation to learn English

vocabulary.

J.Eng.Educ. Society. 6:1.

doi: $10.21070 /$ jees.v6i1.1211

\section{INTRODUCTION}

Vocabulary plays an essential role in reading and comprehending a text (August et al., 2005). English language learners who experience slow vocabulary development tend to read texts slower and have poor comprehension. Not to mention, vocabulary indicates a higher level of our language ability as it is reflected in language construction, such as in speaking and writing. Research has demonstrated that English language learners should acquire 3,000 words to understand spoken discourse (Peters \& Webb, 2018; Webb \& Rodgers, 2009) and 8,000 to 9,000 words to understand written discourse (Nation, 2006; Peters \& Webb, 2018).

Some studies imply that vocabulary development is through incidental learning (Nation, 2020; Renandya \& Jacobs, 2016; Webb, 2015) provides large amounts of L2 spoken input that contributes to the development of vocabulary knowledge. However, incidental vocabulary learning may be beneficial for students who have a genuine interest and understand the importance of vocabulary development. These students may be internally motivated to learn without requiring the external push. 
They have strong self-willingness to be integrated with the English socio-cultural context rather than for career purposes. Numerous studies confirmed that intrinsic motivation leads to better conceptual learning, more cognitive flexibility, greater creativity, and enhanced wellbeing (Ryan \& Deci, 2000).

However, the preliminary study indicated that it would not be an easy task for English language teachers since not all students are equally and highly motivated. Students perceived English as a foreign language as a complex subject to be mastered. Not to mention, the socio-cultural factor, such as their circle of friends who are attracted to nonEnglish songs and movies, plays a significant factor affecting students' low motivation and interest. Besides, teaching English as a foreign language will be challenging compared to English as a second language due to limited classroom time. This may be a decisive predictor of students' achievement to expand their range of vocabulary. English language teachers devote their time to set their teachinglearning process to be attractive to help students mastering some new vocabularies (Kingsley \& Grabner-Hagen, 2018). Teachers may integrate the use of some teaching strategies, media, and tools to gain any attention from their students, not to mention the use of games in the educational context.

Various forms of gaming have been used in teaching English. Jirasevijinda \& Brown (2010) argued that gaming could be an attractive and effective teaching strategy for teaching any subjects that could be considered as problematic and uninteresting, including English. Education games (hereafter, called gamification) offer practical, engaging, interactive, fun and motivating (Beylefeld \& Struwig, 2007) and build a positive learning atmosphere. Even, Blakely et al. (2009) underlined that using games as strategies and tools may develop students' long-term retention.

For this study, we investigated the jeopardy game as a teaching strategy in English classroom instruction to motivate students to learn English vocabulary. Jeopardy classroom instruction is an example of gamification, which is defined as an educational game to deliver certain educational content (Simkin, 2013). Jeopardy game is a game board adopted from a popular TV show with six question-answer categories. Each question in the different categories or columns is displayed from easy to difficult with increasing point values $(\$ 100$ to $\$ 500)$ (Leach \& Sugarman, 2005). As a learning strategy, the jeopardy game fits for teaching students in a group with a range of skill or knowledge levels (Silberman, 1996). Players or teams need to answer the questions correctly, if not, the dollar/point value would be deducted from their scores.

A study by Revere (2004) verified that the improvement of the students' content mastery and their course satisfaction after playing Jeopardy in class. Jeopardy is a technique within an active learning method that is perceived as having many benefits, such as the high level of learner engagement (Grady et al., 2013) and its immediate feedback procedure (Revere, 2004). Benek-Rivera \& Mathews (2004) testified that Jeopardy has interactive instruction or active learning.
Students are more engaged in the teaching-learning process compared to traditional classroom instruction. However, these studies seem to fail to explain the extent of the use of Jeopardy in classroom instruction (Grady et al., 2013), fail to control the equal participation within groups (Benek-Rivera \& Mathews, 2004), and fail to describe how Jeopardy benefits classroom assessment (Revere, 2004). These studies testify how Jeopardy could be used but need some improvements in its implementation. Based on these particular reasons, this study aims to explain the extent of the implementation of Jeopardy to boost the students' learning motivation, particularly in learning English vocabulary.

\section{METHODS}

To answer the research question, this study used the action research method (AR) as its research design. The use of action research was to improve the quality of the teaching and learning process, particularly on the learner's motivation to learn vocabulary by integrating jeopardy classroom instruction.

This study was carried out in two iterative cycles: Cycle 1 (July - August 2019) and Cycle 2 (August - September 2019) adjusted with (1) the students' intrinsic motivation improvement to learn vocabulary, we referred to Gardner's (1985) attitude/motivation test battery, (2) better learning ambiance, and (3) score improvements. Each cycle had four main stages of planning, acting, observing, and reflecting, as reflected in figure 1.

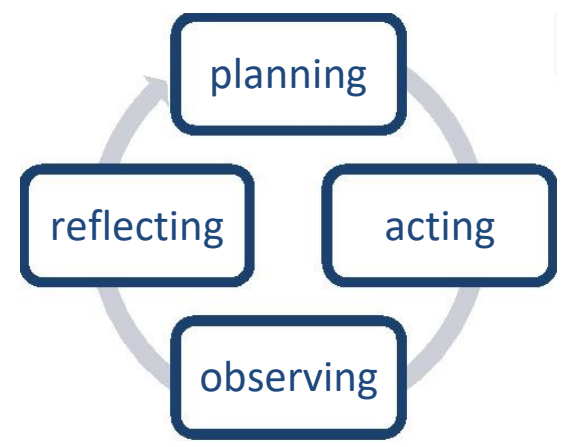

FIGURE 1 | The iterative steps of Action Research

\section{Planning}

In stage 1 (planning), we identified the problems in accordance with the implemented curriculum 2013. On the identification of the problems, we observed the conditions that might affect the students' intrinsic motivation to learn and the most challenging problem for them. Based on the preliminary result, we set our focus on vocabulary improvement since it functions as the basic knowledge for the students. These results shaped our teaching scenario, such as the materials, tools, media, approaches, methods, and strategies to be used to improve the problems (see Figure 2, as an example). The teaching scenario was adjusted with Jeopardy as the primary strategy for classroom instruction. In this stage, we also designed the classroom observation form to see behavior/attitude changes and learning situations during the teaching-learning activities. 


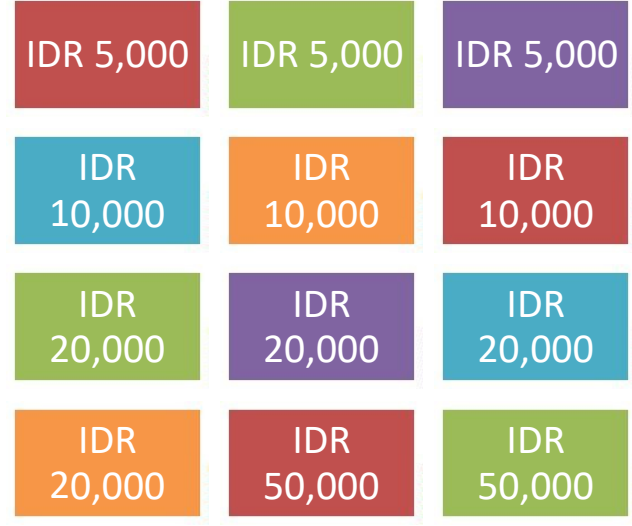

FIGURE 2 | The constructed Jeopardy Game

\section{Acting}

In stage 2 (acting), we collaborated to perform our teaching plan that has been proposed in the previous stage. In acting out, we tried to maintain our portion to talk with the focus on the students' improvement.

In setting the class with jeopardy classroom instruction, we taught them by building their background knowledge. We used an exciting video to grasp their attention towards the new vocabulary introduced to them. To start implementing Jeopardy in our classroom, we organized our students into 8 groups of 4 students. We preferred to team up the students and have them compete with each other (Bee $\underline{\&}$ Hayes, 2005). It aimed to appeal to their attraction and increase the students' involvement. The game began with tossing a coin to decide which group would have the first opportunity to select a question category based on a particular rupiah amount (e.g., IDR 5.000, IDR 10.000, IDR 20.000, and IDR 50.000). The more money the students might choose the more difficult question that the students might have. As in the TV show, the students had 10 seconds to answer the question. They had to introduce themselves, answer the prompts correctly, and use good and proper vocabulary. We collaborated to decide whether the answer given was correct or not. If the group member successfully answered the questions, they might keep the card and take the counterfeit money. The team with the biggest amount of money won the jeopardy game.

\section{Observing}

The observing stage (stage 3) was an ongoing process that was done simultaneously as the acting stage (stage 2). During this stage, we observed the class situation by implementing a chosen strategy. At this stage, we gathered information such as the strengths, weaknesses, opportunities, and threats of the strategy. We started observing to analyze the teaching-learning process, such as the learning ambiance right from the acting stage started in accordance with the constructed classroom observation.

\section{Reflecting}

The last stage was the reflection stage. All of the observed acting plan results were contemplated and discussed whether the teaching strategy improved classroom conditions, developed the students' motivation, and assisted students in learning English vocabulary. The reflection results were to see whether the implemented scenario needed to be revised and improved.

\section{Participants}

The participants involved 32 seventh graders of a public school in Magelang whose ages ranged from 12-13 years old. These participants were chosen along with the new school admission system in 2019 that the central government ruled schools to accept students based on the school zoning system. The school is reputable with its best academic performances for more than decades in Magelang Municipality, but the new zoning admission system causes a class with significant ability differences. The participants were purposively selected since the class learning motivation was varied compared to the other classes.

TABLE 1 | Demographic Information about the respondents

\begin{tabular}{ll} 
Age & \\
Below 12 & 14 \\
After 13 & 18 \\
Gender & \\
Male & 12 \\
Female & 20 \\
\hline
\end{tabular}

\section{Data Collection}

To collect data, there were some instruments used (i) classroom observation form, (ii) questionnaire, and (iii) written test. The observation sheet was used to document any qualitative data, such as behavior and activity during the process. The observation was adapted from Martin's (2003) Student Motivation Scale with six motivation boosters (selfbelief, learning focus, the value of learning, study management, planning and monitoring, and persistence) and four motivation guzzlers (anxiety, low control, failure avoidance, and self-sabotage) to see the students' intrinsic motivation in learning preceding the teaching scenario and the learning progress from Cycle 1 to Cycle 2. The questionnaire was the Likert-scale survey that was adapted from Gardner's (1985) Attitude Motivation Test Battery. It acted as a student's self-assessment to elicit their learning motivation in learning vocabulary. The written test was to document the quantitative data and to see the students' improvement. Since action research is a mixed method, these collected data were analyzed qualitatively and quantitatively. The mixed-method was opted to document any development during the teaching-learning process were verified and supported with the quantification (students' score improvement).

\section{Data Analysis}

This study adopted Burns' (2010) framework with five stages: (1) assembling your data, (2) coding the data, (3) comparing the data, (4) building meanings and interpretations, (5) reporting the outcomes. Burns (2010) defines assembling data as collecting all the data, reviewing the questions, and going through them to find patterns, ideas, and trends. Coding the data means refining into more specific patterns and identifies the qualitative data. Comparing the data was to triangulate different sets of data and display them in charts. Building meanings and 
interpretations is essential to see the abstract concepts which could be done by thinking deeply, posing questions, and refining personal theories. Reporting the outcomes deals with presenting the research and organizes the whole story of the research.

\section{RESULTS AND DISCUSSION}

\section{Pre-cycle phase}

The pre-cycle phase preceded the four stages carried out in cycle 1 , the students were observed to see their motivation in learning vocabulary tailored from Martin's (2003) Student Motivation Scale. The use of an adaptable scale was to observe a view of conditions and the level of students' motivation in learning vocabulary before the activities were carried out.

TABLE 2 | Student motivation Level in learning vocabulary in the Pre-cycle Phase

\begin{tabular}{|c|c|c|}
\hline Motivation Descriptor & Mean & $\begin{array}{l}\text { Motivational } \\
\text { Level }\end{array}$ \\
\hline \multicolumn{3}{|l|}{ Motivation boosters } \\
\hline Self-belief & 2.41 & Low \\
\hline Learning focus & 2.00 & Low \\
\hline Value of learning & 3.00 & Moderate \\
\hline Study management & 2.13 & Low \\
\hline Planning & 2.00 & Low \\
\hline monitoring & 1.67 & Low \\
\hline \multicolumn{3}{|l|}{ Persistence } \\
\hline Motivation guzzlers & & \\
\hline Anxiety & 1.45 & Low \\
\hline Low control & 2.15 & Low \\
\hline Failure avoidance & 1.93 & Low \\
\hline Self-sabotage & 2.07 & Low \\
\hline
\end{tabular}

(Source: Martin, 2003)

Table 2 describes the students' motivation level in learning vocabulary in ten indicators with three different low to moderate degrees of motivation. Table 2 shows that the participants are likely not to have strong self-belief and confidence, learning focus, study management, planning \& monitoring, and persistence toward their ability to learn vocabulary, learning focus, even though they value the importance of vocabulary learning. These data were in line with their self-assessment with Gardner's (1985) Attitude Motivation Test Battery in Figure 3.

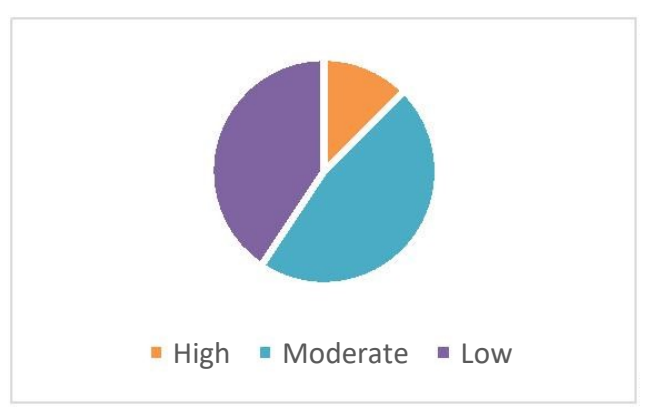

FIGURE 3 | Students' Motivation in Learning Vocabulary in Pre-Cycle Phase
Figure 3 describes the students' motivation level in learning vocabulary in three different categories of lowmoderate-and-high motivation. The chart shows that 15 students (almost 50\%) had moderate motivation in learning vocabulary. The students in this category paid attention to the teaching instruction and did the assignment, but had difficulty learning vocabulary due to the fact that their arguments that English is only one of the subjects they have to pass and not to fail. Meanwhile, 13 students had low motivation $(41 \%)$ as seen from their behavior attitude: they tend to sit with a slump, slouch position, lean back on the chair, or put their heads on the table. Students with low motivation to learn vocabulary were situated in difficult situations between their low ability to understand the instruction and their terrifying feelings when learning with peers who have moderate and high motivation. They did not know how to join the class interaction and preferred to be silent rather than make mistakes, as seen from their behavior. The chart also depicts the fact that only four students $(9 \%)$ had a high motivation to learn vocabulary. The students had their motivation beyond passing the exam, but they wish to use the vocabulary to interact with Native English Speakers.

The big gap between high motivated and low motivated students led to the conclusion that the existing teachinglearning process requires some improvement and needs to be rectified and solved in proper action. It could be perceived that students' motivation could be changed into a positive trend if the classroom condition changed into a better ambiance by applying Jeopardy game as the main classroom strategy, and they had lower anxiety in learning.

\section{Cycle 1 Phase}

Cycle 1 was the initial phase of implementing the four stages of planning, acting, observing, and reflecting that took for about eight meetings. Cycle 1 was (1) to solve the classroom problems on the students' motivation in learning vocabulary ranging from low to moderate level as indicated in the precycle phase, (2) to describe the extent of the implementation of Jeopardy Classroom Instruction to boost the students' learning motivation in learning English vocabulary, and (3) to report the behavioral and academic changes from the precycle phase to Cycle 1 phase. These were reported from the three instruments: classroom observation forms, questionnaires, and written test results.

TABLE 3 | Student motivation Level in learning vocabulary in the Cycle 1 Phase

\begin{tabular}{lcc}
\hline Motivation Descriptor & Mean & $\begin{array}{c}\text { Motivational } \\
\text { Level }\end{array}$ \\
\hline $\begin{array}{l}\text { Motivation boosters } \\
\text { Self-belief }\end{array}$ & 3.00 & Moderate \\
Learning focus & 3.20 & Moderate \\
Value of learning & 4.00 & High \\
Study management & 2.30 & Low \\
Planning and & 2.12 & Low \\
monitoring & 1.93 & Low \\
Persistence & & \\
\hline
\end{tabular}




\begin{tabular}{lcc}
\hline Motivation guzzlers & & \\
Anxiety & 2.00 & Low \\
Low control & 2.70 & Moderate \\
Failure avoidance & 2.45 & Moderate \\
Self-sabotage & 2.35 & Moderate \\
\hline
\end{tabular}

(Source: Martin, 2003)

Table 3 indicates the classroom observation on the students' motivation level in learning vocabulary in Cycle 1. The Jeopardy Classroom Instruction was able to portray some behavioral changes with better motivation boosters and motivation guzzlers. These were indicated from their value of learning, learning focus, and self-belief to represent the existence of enthusiasm for learning vocabulary. During the implementation of Jeopardy Classroom Instruction, we witnessed how the students looked happy and started to involve themselves in the Jeopardy Classroom Instruction in learning vocabulary. They showed a positive attitude toward learning and had a solid willingness to answer the questions correctly. It could be seen that they tried hard to memorize all vocabulary that had been taught before (see Figure 4).

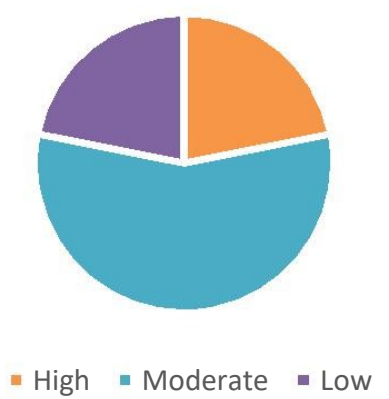

FIGURE 4 | Students' Motivation in Learning Vocabulary in Cycle 1 Phase

Figure 4 discussed the students' self-assessment of their motivation in learning vocabulary with $22 \%$ of highly motivated students, $56 \%$ of moderate-motivated, and $22 \%$ of low-motivated. The data in Figures 3 and Figure 4 highlighted that students with relatively low motivation were attracted and motivated by the Jeopardy Classroom Instruction to learn vocabulary. Comparing two charts in Figures 3 and Figure 4, there was a considerably significant improvement in the scale of low motivated students from $41 \%$ to $22 \%$. These were reflected in their written test improvement from the pre-cycle test (Mean Score $=62.31$ ) to Cycle 1 test $($ Mean Score $=69.81)$ (See Table 5). The Cycle 1 test results supported the claim of how the teaching ambiance was positively different. Students began to have a better comprehension of using vocabulary, and these were reflected in their performance. These findings were in accordance with Spolsky's (1998) theory that motivated students will pay more attention and learn more quickly and better. Even though the classroom ambiance depicted how students were enthusiastic and motivated and how students' scores showed an upward trend of 7.50 points, 12 students failed to get the minimum passing grade (Min Score $=75$ ). It is perceived that individual motivation needs to be boosted up. These underlying reasons were to justify the furtherance of the classroom action research in the second phase (Cycle 2 phase).

\section{Cycle 2 Phase}

Cycle 2 was the continuation of Cycle 1, and it aimed to build individual motivation in learning vocabulary and achieve the minimum passing grade. The positive drifts on the classical teaching ambiance in Cycle 1, need to be maintained and adjusted to develop and facilitate individual motivation in learning vocabulary. For these reasons, the minor but possible variation of the grouping system in the Jeopardy Classroom Instruction was carried out, i.e., from grouping students to pairing them. With pairing up, we believed the essence of good collaboration could be maintained, and the individual motivation in learning vocabulary could be supported without any substantial changes in the procedures of Jeopardy Classroom Instruction. The classroom observation indicates that the implementation of pairs was preferable and motivating for the students to be actively involved in the Jeopardy Classroom Instruction and to learn vocabulary than the big group size.

TABLE 4 | Student motivation Level in learning vocabulary in the Cycle 2 Phase

\begin{tabular}{|c|c|c|}
\hline Motivation Descriptor & Mean & $\begin{array}{l}\text { Motivational } \\
\text { Level }\end{array}$ \\
\hline \multicolumn{3}{|l|}{ Motivation boosters } \\
\hline Self-belief & 3.50 & High \\
\hline Learning focus & 3.77 & High \\
\hline Value of learning & 4.23 & High \\
\hline Study management & 3.00 & Moderate \\
\hline Planning & 2.90 & Moderate \\
\hline monitoring & 2.40 & Moderate \\
\hline Persistence & & \\
\hline \multicolumn{3}{|l|}{ Motivation guzzlers } \\
\hline Anxiety & 2.30 & Moderate \\
\hline Low control & 3.83 & High \\
\hline Failure avoidance & 3.75 & High \\
\hline Self-sabotage & 3.70 & High \\
\hline
\end{tabular}

(Source: Martin, 2003)

Table 4 reflects the classroom observation on the students' motivation level in learning vocabulary in the Cycle 2 phase, and it implies the considerable improvement of the students' motivation in learning vocabulary. The slight adjustment from big group size to pair group of the Jeopardy Classroom Instruction procedure was able to give significant results on the students' motivation, particularly on how they value the importance of learning vocabulary, their focus, and their belief of success in learning vocabulary. With the procedure, the students are likely to learn to control the motivation guzzlers such as anxiety, low control, failure avoidance, and self-sabotage. This means that more students were motivated to learn vocabulary and actively participated in the Jeopardy Classroom Instruction. This classroom situation was likely in accordance with the questionnaire results (Figure 5) and their written test results (Table 5). 


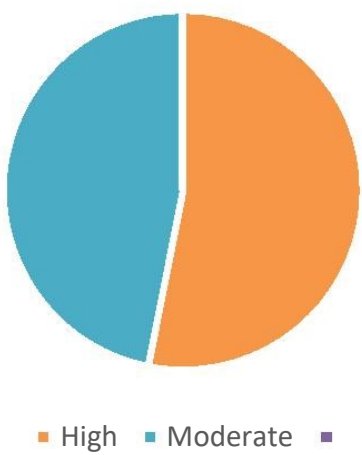

FIGURE 5 | Students' Motivation in Learning Vocabulary in Cycle 2 Phase

Figure $\underline{5}$ describes how students assessed their motivation in learning vocabulary in Cycle 2 Phase with $53 \%$ of highly motivated students and $47 \%$ of moderatemotivated. These data informed how pairing students with a slight variation instead of grouping them benefited and motivated them to learn vocabulary with the Jeopardy Classroom Instruction. These data were in accordance with the written test improvement from Cycle 1 test (Mean Score $=69.81$ ) to Cycle 2 test (76.79) (See Table 5) with all of the students passed the minimum passing grade and three students had the minimum passing grade. The data indicated how each student felt energized and motivated in learning vocabulary with the Jeopardy Classroom Instruction.

TABLE 5 | Students' score improvement between pre-cycle test, Cycle 1 test, and Cycle 2 test

\begin{tabular}{lccc}
\hline & Pre- & Cycle & Cycle \\
& Cycle & 1 & 2 \\
Average Score & 62.31 & 69.81 & 76.79 \\
$\begin{array}{l}\text { Students with } \\
\text { below the passing }\end{array}$ & 19 & 12 & 0 \\
grade =75 & 80 & 85 & 91 \\
Max Score & 59 & 62 & 75 \\
Minimum Score & & & \\
\hline
\end{tabular}

Table 5, which depicted the students' score progress, implied the benefits of Jeopardy Classroom Instruction to motivate students in learning vocabulary and indicated how students passed the required passing grade in Cycle 2. The research has answered its aim to see the extent of the implementation of Jeopardy Classroom Instruction to motivate students to learn English vocabulary. At this point, this research was completed accordingly and no longer continued to the next phase. The students' score improvement from pre-cycle to Cycle 1 and Cycle 2 as in Table 4 demonstrated how students were more motivated and engaged in Jeopardy Classroom Instruction to learn vocabulary.

The study was then triangulated to shed light on the implementation of Jeopardy Classroom Instruction to nurture students' motivation to learn vocabulary. They experienced considerable improvement from July to September 2019, which was captured by the researchers' observation, questionnaire, and students' scores. In the beginning, their motivation was dominated by nonenthusiastic and silent students rather than by the highly motivated students. The improvement of score and the observation were in line with the students' perceptions in which students are in favor of game-based instruction than in any didactic teaching. However, by the end of the project, Jeopardy Classroom Instruction acted as an effective way to boost students' motivation in learning vocabulary in a language classroom setting, and eventually, Jeopardy Classroom Instruction was able to help the students to get better vocabulary scores.

In this regard, this study upheld the value of Jeopardy Classroom as an adjunct to a conventional language classroom condition, and this study corresponded with some prior studies (Benek-Rivera \& Mathews, 2004; Grady et al.,2013; Revere, 2004). This is due to some reasons. First, the study verifies how Jeopardy Classroom Instruction helps the students improve their self-belief. Students who did not have a positive attitude and self-esteem towards their learning capability, in the beginning, started to gain their self-confidence. They began to manage their study plan to learn vocabulary. Also, they are encouraged to discuss the answers of the questions. With regards to win the game, they started to value their learning and build communication within groups. Second, the study testifies how the Jeopardy Classroom Instruction could hinder some motivation guzzlers such as anxiety, low control, failure avoidance, and self-sabotage. As they found that the Jeopardy Classroom Interaction is both challenging and pleasant, they began to manage their fear and nervousness and not avoid any possible failure during the classroom practice. They learned that remaining silent might sabotage their learning process. With the triumphant activity, they start to learn to be involved in the class activities. These findings become the most substantial contribution to vocabulary attainment.

With the employment of Action Research, these findings could snapshot a more thorough picture during the classroom practices than some prior studies which were investigated under survey research (Grady et al., 2013)or experimental research (Dehghanzadeh et al., 2019). The first study concluded the efficacy of the game only based on the students' perceptions and attitudes, while the latter study, which suggested a successful vocabulary learning, drew its conclusion only based on the immediate test results and did not shed light on the delayed effect of the game for vocabulary learning. Hence, the study functions as an adjunct to these studies as mentioned earlier.

\section{CONCLUSION}

Jeopardy Classroom Instruction could be considered used as a strategy to motivate students to learn vocabulary and, even in the wider context is to instruct the language classroom. It helps the classroom teachers develop the quality of the teaching-learning process, as seen from three main indicators, such as participation/involvement, motivation, and score. With its active learning principles and jeopardy 
classroom instruction, Jeopardy classroom instruction has successfully appealed to the students' participation in winning the vocabulary game. The passive students were challenged and motivated to participate in it. Jeopardy classroom instruction as a game-assisted language learning has helped students attain self-belief, learning focus, the value of learning, study management, planning and monitoring, and persistence. Not to mention, this study suggests how Jeopardy Classroom Instruction overcome some guzzlers such as learning anxiety, low control, failure avoidance, self-sabotage, and the students worked harder to memorize all of the vocabulary taught. Jeopardy classroom instruction could be seen as the model of vocabulary learning. Last but not least, Jeopardy could fit into any teaching materials and improve the quality of the teachinglearning process.

\section{ACKNOWLEDGEMENTS}

This research was supported and funded by the Ministry of Research, Technology, and Higher Education, remarkably the Director-General of Human Resource Development through the Program Penugasan Dosen di Sekolah (Lecturers Go to School) 2019.

\section{REFERENCES}

August, D., Carlo, M., Dressler, C., \& Snow, C. (2005). The critical role of vocabulary development for English language learners. Learning Disabilities Research and Practice, 20(1), 50-57. https://doi.org/10.1111/j.1540-5826.2005.00120.x

Bee, S., \& Hayes, D. C. (2005). Using the Jeopardy game to enhance student understanding of accounting information systems (AIS) exam material. Review of Business Information Systems (RBIS), 9(1), 69-78. https://doi.org/10.19030/rbis.v9i1.4471s

Benek-Rivera, J., \& Mathews, V. E. (2004). Active Learning with Jeopardy: Students Ask the Questions. Journal of Management Education, 28(1), 104-118. https://doi.org/10.1177/1052562903252637

Beylefeld, A. A., \& Struwig, M. C. (2007). A gaming approach to learning medical microbiology: Students' experiences of flow. Medical Teacher, 29(9-10), 933-940. https://doi.org/10.1080/01421590701601550

Blakely, G., Skirton, H., Cooper, S., Allum, P., \& Nelmes, P. (2009). Educational gaming in the health sciences: Systematic review. Journal of Advanced Nursing, 65(2), 259-269. https://doi.org/10.1111/j.13652648.2008.04843.x

Burns, A. (2010). Doing action research in English language teaching: A guide for practitioners. Routledge.
Dehghanzadeh, H., Fardanesh, H., Hatami, J., Talaee, E., \& Noroozi, O. (2019). Using gamification to support learning English as a second language: a systematic review. In Computer Assisted Language Learning. (pp. 1-24). https://doi.org/10.1080/09588221.2019.1648298

Gardner, R. C. (1985). Social psychology and second language learning: The role of attitudes and motivation. E. Arnold.

Grady, S. E., Vest, K. M., \& Todd, T. J. (2013). Student attitudes toward the use of games to promote learning in the large classroom setting. Currents in Pharmacy Teaching and Learning, 5(4), 263-268. https://doi.org/10.1016/j.cptl.2013.01.008

Jirasevijinda, T., \& Brown, L. C. (2010). Jeopardy! (C): An innovative approach to teach psychosocial aspects of pediatrics. Patient Education and Counseling, 80(3), 333-336. https://doi.org/10.1016/j.pec.2010.06.002

Kingsley, T. L., \& Grabner-Hagen, M. M. (2018). Vocabulary by gamification. The Reading Teacher, 71(5), 545-555. https://doi.org/10.1002/trtr.1645

Leach, G. J., \& Sugarman, T. S. (2005). Play to win! Using games in library instruction to enhance student learning. Research Strategies, 20(3), 191-203. https://doi.org/10.1016/j.resstr.2006.05.002

Martin, A. J. (2003). The Student Motivation Scale: Further Testing of an Instrument that Measures School Students' Motivation. Australian Journal of Education, 47(1), 88-106. https://doi.org/10.1177/000494410304700107

Nation, I. (2006). How large a vocabulary is needed for reading and listening? Canadian Modern Language Review, 63(1), 59-82. https://doi.org/10.3138/cmlr.63.1.59

Nation, Ian. (2020). Principles guiding vocabulary learning through extensive reading.

Peters, E., \& Webb, S. (2018). Incidental vocabulary acquisition through viewing L2 television and factors that affect learning. Studies in Second Language Acquisition, 40(3), 551-577. https://doi.org/10.1017/S0272263117000407

Renandya, W. A., \& Jacobs, G. M. (2016). Extensive reading and listening in the L2 classroom. In W. A. Renandya \& H. P. Widodo (Eds.), English Language Teaching Today. (Vol. 5, pp. 97-110). Springer, Cham. https://doi.org/10.1007/978-3-319-38834-2_8

Revere, L. (2004). Classroom Jeopardy: A winning approach for improving student assessment, performance, and satisfaction. Decision Line, 35(3), 3-6.

Ryan, R. M., \& Deci, E. L. (2000). Self-determination theory and the facilitation of intrinsic motivation, social development, and well-being. American Psychologist, 55(1), 68-78. https://doi.org/10.1037/0003-066X.55.1.68

Silberman, M. L. (1996). Active learning: 101 strategies to teach any subject. Allyn and Bacon. 
Simkin, M. G. (2013). Playing Jeopardy in the Classroom: An Empirical Study. Journal of Information Systems Education, 24(3), 203.

Spolsky, B. (1998). Conditions for second language learning: Introduction to a general theory (4. impr). Oxford Univ. Press.

Webb, Stuart, \& Rodgers, M. P. H. (2009). Vocabulary demands of television programs. Language Learning, 59(2), 335-366. https://doi.org/10.1111/j.14679922.2009.00509.x

Webb, S. (2015). Extensive viewing: Language learning through watching television. In Language Learning Beyond the Classroom (D. Nunan \& J.C. Richards). New York: Routledge.
Conflict of Interest Statement: The authors declare that the research was conducted in the absence of any commercial or financial relationships that could be construed as a potential conflict ofinterest.

Copyright (C) 2021 Widya Ratna Kusumaningrum and Endang Binarti. This is an open-access article distributed under the terms of the Creative Commons Attribution License (CC BY). The use, distribution or reproduction in other forums is permitted, provided the original author(s) and the copyright owner(s) are credited and that the original publication in this journal is cited, in accordance with accepted academic practice. No use, distribution or reproduction is permitted which does not comply with these term. 